\title{
Death of HT29 adenocarcinoma cells induced by TNF family receptor activation is caspase-independent and displays features of both apoptosis and necrosis
}

\author{
CA Wilson ${ }^{1}$ and $\mathrm{JL}$ Browning ${ }^{*, 1}$ \\ ${ }^{1}$ Department of Exploratory Biology, Biogen, 12 Cambridge Center, Cambridge, \\ MA 02142, USA \\ * Corresponding author: JL Browning, Department of Exploratory Biology, \\ Biogen, 12 Cambridge Center, Cambridge, MA 02142, USA; \\ Tel: 617 679-3312; Fax: 617 679-2304; E-mail: jeff_browning@biogen.com
}

Received 7.12.01; revised 26.1.02; accepted 22.7.02

Edited by B Osborne

\begin{abstract}
The HT29 adenocarcinoma is a common model of epithelial cell differentiation and colorectal cancer and its death is an oftanalyzed response to TNF family receptor signaling. The death event itself remains poorly characterized and here we have examined the involvement of caspases using pan-caspase inhibitors. zVAD-fmk did not block death of HT29 cells in response to activation of the Fas, TRAIL, TNF, TWEAK and LT $\beta$ receptors. The secondary induction of TNF or the other known bona fide death inducing ligands did not account for death following $\mathrm{LT} \beta$ receptor activation indicating that TNF family receptors can trigger a caspase-independent death pathway regardless of the presence of canonical death domains in the receptor. To provide a frame of reference, the phenotype of HT29 death was compared to four other TNF family receptor triggered death events; Fas induced Jurkat cell apoptosis, TNF/zVAD induced L929 fibroblast necrosis, TNF induced death of WEHI 164 fibroblastoid cells and TNF/zVAD induced U937 death. The death of HT29 and U937 cells under these conditions is an intermediate form with both necrotic and apoptotic features. The efficient coupling of TNF receptors to a caspase-independent death event in an epithelial cell suggests an alternative approach to cancer therapy.

Cell Death and Differentiation (2002) 9, 1321 - 1333. doi:10.1038/ sj.cdd. 4401107
\end{abstract}

Keywords: TNF; caspase-independent; apoptosis; necrosis

Abbreviations: AlF, apoptosis inducing factor; DAPI, 4,6 diaminophenyl-2-phenylindole; IFN $\gamma$, interferon- $\gamma$; JNK, cJun $\mathrm{N}$ terminal kinase; LT $\beta$ R, lymphotoxin- $\beta$ receptor; MTT, 3-(4,5-dimethylthiazol2-yl) 2,5 diphenyltetrazolium bromide; $P C D$, programmed cell death; $\mathrm{PI}$, propidium iodide; $\mathrm{ROS}$ reactive oxygen species; TNFR, tumor necrosis factor receptor; TRAF, Tumor necrosis factor receptor associated factors; TRAIL-R, TRAIL receptor; 7AAD, 7amino actinomycin D

\section{Introduction}

Receptors in the TNF family can initiate both canonical apoptotic and necrotic death events. ${ }^{1}$ Prototypical apoptosis follows activation of the Fas receptor on $\mathrm{T}$ cells leading to caspase activation and a cascade of events eventually culminating in the various hallmarks of apoptosis. ${ }^{2,3}$ Yet even in this familiar case, Fas/FADD can trigger necrosis in T cells in the absence of caspase signaling. ${ }^{4,5}$ In the well-studied L929 fibroblast line, Fas activation triggers apoptosis while TNF initiates a necrotic event that is actually enhanced by caspase inhibition. ${ }^{1}$ Similarly, TNF signaling in the presence of caspase inhibitors was reported to lead to the necrosis of NIH3T3 fibroblasts and the myeloid U937 cell line. ${ }^{6}$ It has been dogmatic that apoptosis is only initiated by those TNF family receptors containing an intracellular death domain capable of coupling to the caspase machinery. Paradoxically, however, several TNF family receptors lacking canonical death domains can trigger an apoptotic-like death. This phenomenon results from the secondary induction of TNF secretion in some cell lines leading to classical apoptosis via the death domain containing p55 TNF receptor. ${ }^{7,8}$ Therefore the question of whether a non-death domain containing receptor in the TNF family can directly trigger a death pathway remains unresolved.

Two additional categories of death, apoptosis-like programmed cell death (PCD) and necrosis-like PCD, were defined as intermediates between canonical apoptosis and necrosis. ${ }^{9}$ Cells undergoing both intermediate types of death display some aspects of apoptotic mechanisms, but are distinguished by the patterns of chromatin condensation. These intermediates may correlate with several of the variations of PCD observed in vivo. $^{10,11}$ The heterogeneity of death mechanisms has been underscored by recent observations questioning the exact role played by caspases in some critical physiological events. For example, lymphocytes can undergo caspase-independent death in response to a number of stimuli. ${ }^{12}$ Surprisingly, caspase activity is actually required for T-cell proliferation. ${ }^{13}$ Genetic deletion of caspases has revealed some critical developmental roles, but in general the effects have been underwhelming, leading to speculation of alternate physiologically relevant PCD mechanisms. Release of apoptosis inducing factor (AIF) from the mitochondria leads to caspase-independent PCD and represents a potential mechanism to account for some of these observations. ${ }^{14}$ From these various studies, it appears that collapse of the mitochonrdrial membrane potential, cytochrome $c$ and AIF release, zeiosis, phosphatidylserine translocation, chromatin cleavage to $50 \mathrm{kDa}$ pieces, condensation and margination can be triggered independently of caspase activity. DNA cleavage into 
nucleosome sized pieces appears dependent upon caspase activation of the CAD nuclease. ${ }^{9}$

The adenocarcinoma cell line HT29 is often used in the TNF field as an assay system and this cell also serves as a model of intestinal epithelial cell differentiation and colorectal cancer. We are interested in the death of HT29 cells that follows activation of various members of the TNF receptor family and in particular the death induced by an anti-LT $\beta$ R agonist antibody. ${ }^{15-21}$ This antibody has demonstrated anti-tumor potential in vivo. ${ }^{15}$ Death of this cell when induced by TNF family receptors is somewhat unusual as it is relatively slow and when analyzed with cells grown on plastic, interferon- $\gamma$ (IFN- $\gamma$ ) co-signaling is required for death. ${ }^{22,23}$ Moreover, HT29 death is enhanced by IFN- $\gamma$ even when initiated by non-TNF related proapoptotic stimuli such as staurosporine, cisplatin and ceramides, but not by agents that induce necrosis. ${ }^{19}$ Thus IFN- $\gamma$ affects downstream signaling events and may toggle the cell's response to receptor activation between death and differentiation.

Given this background, we were interested in characterizing the death initiated by LT $\beta$ R and TNFR activation in the human HT29 and murine WEHI 164 cell systems. ${ }^{15,24}$ To provide a frame-of-reference, HT29 cells were compared to well-characterized apoptotic and necrotic events in Jurkat and L929 cells and the TNF/zVAD-fmk induced death of U937 cells. All death events initiated by receptors in the
TNF family have been reported to be caspase-dependent except TNF/zVAD induced necrosis in L929, NIH3T3 and U937 cells, LIGHT triggered Hep3B death and recent reports on signaling via the Taj and Wengen receptors. ${ }^{25,26}$ Therefore, we have questioned whether death of the epithelial HT29 cell induced by TNF family receptors either with or without death domains is actually caspasedependent and more specifically whether this death is directly dependent on the secondary secretion of other TNF family ligands, e.g. TNF, Fas-L, TWEAK or TRAIL. Here we find that caspase-independent death of HT29 cells can be induced by activation of TNF family receptors either with or without death domains and the mechanism does not involve the secondary generation of death-inducing ligands.

\section{Results}

\section{HT29 death is not blocked by the general caspase inhibitor zVAD-fmk}

We used the general caspase inhibitor zVAD-fmk to assess the role of caspases in HT29 death in a 3-4 day growth assay (Figure 1A). In this well-defined assay, the lack of growth is due to death and not simply anti-proliferative effects. ${ }^{15,18-20}$ Death induced by activation of TNF family receptors including TNF-R, LT $\beta$ R, Fas, TRAIL-R, IFN- $\gamma-\mathrm{R}$ and TWEAK-R was not blocked by zVAD-fmk treatment (Figure 1A, compare open
A. HT29

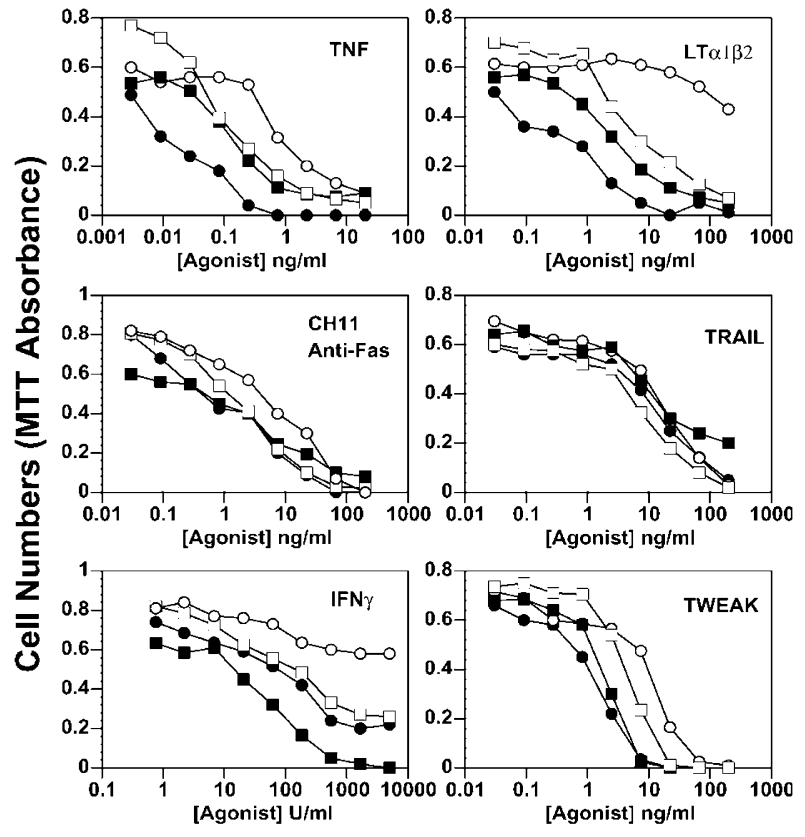

B. JURKAT
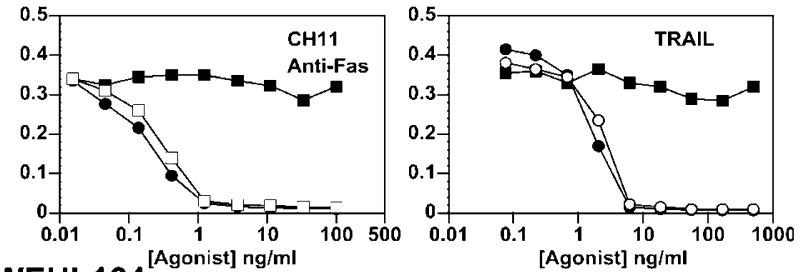

C. WEHI-164
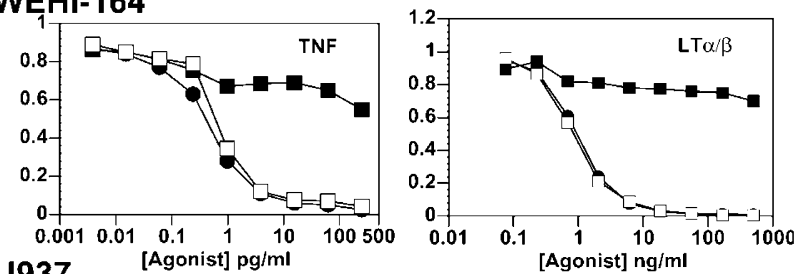

D. 4937
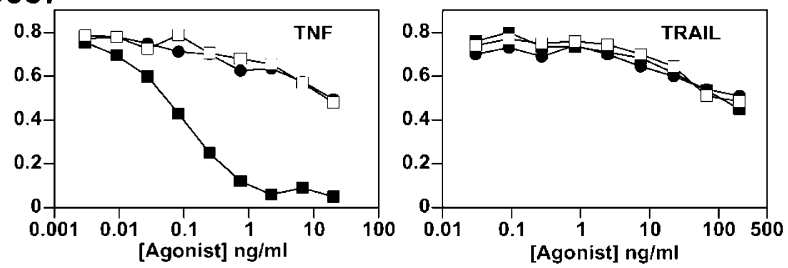

Figure 1 Effects of the general caspase inhibitor zVAD-fmk on cell viability in 3-4 day growth assays using an MTT readout. Cell death was triggered by activation of the TNF family of receptors in various cell types. Cells were treated with the indicated concentrations of the cytokines TNF, TRAIL, TWEAK, LT $\alpha 1 / \beta 2$ and or the anti-Fas agonist mAb in the presence of no additions (closed circle), $50 \mu \mathrm{M}$ zVAD-fmk, final solvent concentration $0.25 \%$ DMSO (closed square), $0.25 \%$ DMSO alone (open square) or $1 \%$ DMSO alone (open circle). Shown are the effects on $(\mathbf{A})$ a human adenocarcinoma line HT29 (block of six graphs), (B) a human T cell line Jurkat, (C) a mouse fibroblastoid line WEHI 164 and (D) a human monocytic leukemia line U937. Human ligands were used in each case except for murine LT $\alpha / \beta$ with WEHI 164 cells. ${ }^{24}$ Wells with TRAIL also contained anti-FLAG mAb M2 $(1 \mu \mathrm{g} / \mathrm{ml})$ to further crosslink the TRAIL-R. IFN $\gamma$ ( $\left.80 \mathrm{U} / \mathrm{ml}\right)$ was present only in the HT29 experiments with TNF ligands. In the HT29 panel where IFN- $\gamma$ alone was used, the $x$-axis is plotted as units of antiviral activity per ml. Direct visual examination confirmed that the decreased MTT readout was due to cell death and not inhibition of cell proliferation in each assay. Data represents the average of duplicate wells and all MTT growth experiments were carried out at least three times with similar results 
and closed squares). zDEVD-fmk (100 $\mu \mathrm{M})$, zVAD-fmk plus zDEVD-fmk, zAAD-cmk (100 $\mu \mathrm{M})$, Ac-YVAD-cmk $(50 \mu \mathrm{M})$ and Boc-D-fmk (BD-fmk, another general caspase inhibitor, ${ }^{27}$ $10-100 \mu \mathrm{M}$ ) similarly had no effect on HT29 death (data not shown). Pretreatment of the HT29 cells for 30 min with zVADfmk or addition of fresh zVAD-fmk after 2 days did not alter the results. Curiously, LT $\beta \mathrm{R}$ or IFN- $\gamma$ triggered $\mathrm{HT} 29$ death was inhibited by higher concentrations of dimethylsulfoxide (Figure 1A, open circles). This effect was maximal at $1 \%$ (data not shown) and indicates a need for caution in the use of this solvent with some cell types. This effect may be due to induction of cellular differentiation by this solvent and the apparent selectivity for $\mathrm{LT} \beta \mathrm{R}$ may result from the relatively slow kinetics of this death event. HT29 cells are known to exist in multiple states indicating a proclivity for differentiation events. $^{32,33}$ In support of this hypothesis, the differentiating agents, sodium butyrate, 1,25 dihyroxyvitamin D3 and dimethylformamide were protective while retinoic acid and dexamethasone did not have an effect (data not shown).

For comparison, several other well-studied death events were examined. The death of the Jurkat $T$ cell lymphoid line following Fas or TRAIL-R activation (Figure 1B) and the SKW 6.4 B cell line following Fas activation (data not shown) was completely blocked by zVAD-fmk. Importantly, these data demonstrate that the caspase inhibitor remained active throughout these long term assays. Similarily, zVAD-fmk completely blocked the death induced by TNF-R or LT $\beta R$ activation in the WEHI 164 fibroblastoid cell line (Figure 1C). It is interesting that WEHI-164 death following LT $\beta R$ activation was caspase-dependent since this receptor lacks a canonical death domain. The U937 line also dies in response to TNF signaling (Figure 1D), although the ATCC derived isolate used in these experiments required high concentrations of TNF in agreement with the previously noted poor sensitivity. ${ }^{30}$ It was reported and we had independently made the same observation that TNF-induced U937 death was dramatically augmented by zVAD-fmk (Figure 1D) and BD-fmk (data not shown). ${ }^{6}$ TRAIL induced death, however, was not enhanced by zVAD-fmk (Figure 1D). LT $\beta$ R activation had no effect on the U937 cells with or without $z V A D-f m k$ (data not shown). The TNF-induced death of THP-1 cells, another human monocytic line, was also potentiated by zVAD-fmk albeit less dramatically, while HL60 cells were not affected (data not shown). A similar enhancement of TNF induced death by zVAD-fmk was reported with the mouse fibroblastoid lines L929 and NIH3T3. ${ }^{6,31}$ Inhibition of caspase activity by zVAD-fmk in these systems was directly verified using fluorgenic YVAD, DEVD and IETD, as representative substrates for group I, group II and group III caspases. ${ }^{32}$ Even at times up to $48 \mathrm{~h}$ after addition of the agonist, caspase activity was not detected in zVAD-fmk treated HT29 cells and similar results were observed for the other lines at $3 \mathrm{~h}$ (data not shown).

\section{Induction of endogenous TNF production does not mediate LT $\beta$ R-induced death in HT29 or WEHI 164 cells}

In some cells, signaling through TNF family receptors lacking death domains, e.g. TNFRII, CD40, CD30 and the TWEAK receptor involved upregulation of endogenous TNF synthesis thereby inducing death indirectly. ${ }^{7,8}$ Accordingly in these systems, blocking antibodies to either TNF or TNFRI inhibit the death induced by ligands that bind to nondeath-domain containing receptors. To determine whether the death of HT29 cells or WEHI 164 cells by LT $\beta$ R signaling occurred by upregulation of TNF synthesis, we used an immobilized agonistic anti-human $\mathrm{LT} \beta \mathrm{R}$ mAb and a murine $\mathrm{LT} \alpha / \beta$ ligand to activate the human and murine receptors. ${ }^{15,24}$ Table 1 shows that blockade of TNF, FasL, TRAIL or TWEAK with either neutralizing antibodies or soluble receptors did not affect the $\mathrm{LT} \beta \mathrm{R}$ triggered death of either cell type. Only $\mathrm{LT} \alpha / \beta$ inhibitors were able to block the death event in this setting. It can be seen in this table that all of the inhibitors used in this study were capable of inhibiting their respective targets in positive control systems even in these long term assay formats. Therefore, secondary induction of the expression of other death inducers does not appear to account for the effects of $\mathrm{LT} \beta \mathrm{R}$ signaling.

\section{Nuclear changes and phosphatidylserine translocation in these death events}

Historically, TNF/IFN $\gamma$ triggered HT29 death was considered to be apoptotic since the nuclei condense, annexin $\mathrm{V}$ binding increases and clear cytoplasmic blebs devoid of organelles can be observed. ${ }^{15,18-20,33-35}$ However, not all facets of this death are consistent with an apoptotic process. The cytoplasmic blebs are similar to those described on L929 cells undergoing Fas-induced apoptosis; however, these blebs may be more indicative of necrosis or post-apoptotic necrosis. ${ }^{1}$ Likewise, in some studies, DNA cleavage in dying HT29 cells was limited to the generation of the large 50$200 \mathrm{~kb}$ fragments often seen in dying epithelial cells rather than the complete nucleosome laddering viewed as a hallmark of conventional apoptosis. ${ }^{34-36}$ To determine if the cells undergo the chromatin condensation and margination characteristic of apoptosis, an electron microscopic analysis was carried out. Following TNFR, Fas or TWEAK-R activation, the chromatin condensed and localized to the nuclear membrane, i.e. marginated. An example of an antiFas treated dying HT29 cell is shown in Figure 2. At this time point, the bulk of the IFN- $\gamma$ treated cells were normal in appearance (untreated control not shown) while dying TNF and TWEAK treated HT29 cells resembled anti-Fas treated cells. The dying cells exhibited rounding and slight cellular swelling which may reflect necrotic or post-apoptotic necrotic events, yet the loss of microvilli, disruption of the mitochondrial cristae without apparent mitochondrial swelling and dilation of the endoplasmic reticulum are features of apoptosis.

Some DNA fragmentation can be detected in HT29 cells following activation of the TNF receptors or Fas. ${ }^{15,18,37,38}$ To determine the level of DNA fragmentation in these experiments, a FACS analysis of PI stained cells was undertaken to monitor DNA cleavage. TNF or anti-LT $\beta$ R agonist antibody treated HT29 cells contained subdiploid DNA and its generation was blocked by zVAD-fmk treatment (Table 2). Likewise, anti-Fas-treated Jurkat cells and TNF-treated U937 cells exhibited increased levels of 
Table 1 The lack of effects of inhibitors of various death inducing TNF ligands on the LT $\beta$ R activation triggered death of HT29 and WEHI 164 cells

\begin{tabular}{|c|c|c|c|c|c|c|c|}
\hline \multirow[b]{2}{*}{ Cell } & \multirow[b]{2}{*}{ Activating agent } & \multicolumn{6}{|c|}{ Agonist concentration at the ED50 (ng/ml) ${ }^{a}$} \\
\hline & & None & Anti-hFasL & Anti-hTNF & Anti-TWEAK & hTRAIL-R2-lg & hLTBR-Ig \\
\hline \multirow[t]{6}{*}{ HT29 } & Anti-LT $\beta$ R & 1.1 & 2.2 & 1.4 & 1.4 & 1.7 & $>300$ \\
\hline & hTNF & 0.1 & - & $>20$ & - & - & - \\
\hline & hTRAIL & 0.2 & - & - & - & 70 & - \\
\hline & hFasL & 3 & $>5000$ & - & - & - & - \\
\hline & hTWEAK & 10 & - & - & $>500$ & - & - \\
\hline & & None & Anti-mFasL & Anti-mTNF & Anti-TWEAK & mTRAIL-R2-Ig & $\mathbf{m L T} \beta \mathbf{R}-\mathbf{I g}$ \\
\hline \multirow[t]{4}{*}{ WEHI-164 } & $\mathrm{mLT} \alpha / \beta$ & 1.0 & 0.9 & 1.0 & 1.2 & 1.0 & $>100$ \\
\hline & mTNF & 0.0001 & - & $>10$ & - & - & - \\
\hline & mTRAIL & 300 & - & - & - & $>15000$ & - \\
\hline & mTWEAK & 0.1 & - & - & $>200$ & - & _ \\
\hline JURKAT & mFasL & 400 & $>40000$ & - & - & - & - \\
\hline
\end{tabular}

${ }^{a}$ MTT proliferation assays were carried out in the absence or presence of the inhibitors of the appropriate mouse or human forms as defined in Materials and Methods. An agonistic anti-LT $\beta / \mathrm{R}$ mAb, CBE11, was used to activate this receptor on HT29 cells, while with the WEHI 164 line, recombinant mLT $\alpha / \beta$ was used to activate LT $\beta$ R. CBE11 was immobilized by capture with an anti-Fc mAb. In the HT29 assays, $80 \mathrm{U} / \mathrm{ml}$ of IFN- $\gamma$ were included, anti-FLAG was present with the hTRAIL and hFasL and anti-His-Tag was present with $\mathrm{mFasL}$ and mTRIAL to further crosslink these ligands. WEHI 164 cells were not sensitive to $\mathrm{mFasL}$ at concentrations up to $5 \mu \mathrm{g} / \mathrm{ml}$

subdiploid DNA and this event was also completely blocked by caspase inhibition (Table 2). As previously reported and reproduced here, TNF did not induce DNA fragmentation in L929 cells undergoing necrosis. Fluorescence microscopy of DAPI stained nuclei was employed to visualize chromatin condensation. Chromatin condensation, i.e. smaller nuclei, was observed in anti-Fas or TNF treated HT29 cells both in the presence and absence of zVAD-fmk (Figure $3 A, B$ ) indicating that the death retained this feature of apoptosis. With anti-Fas, but not TNF, TRAIL or TWEAK treatment, there were fewer condensed nuclei in the presence of zVAD-fmk after 2 days of treatment suggesting that Fas induced death was slowed (data not shown, addressed further below). In contrast, zVAD-fmk effectively prevented chromatin condensation in WEHI 164 cells when triggered by either TNF-R (not shown) or LT $\beta$ R activation (Figure $3 C)$. Thus chromatin condensation was caspase-independent in HT29 cells, but caspase-dependent in WEHI 164 cells.

In the presence of TNF alone, some U937 nuclei condense and break up into large fragments in a classic apoptotic pattern (Figure 3D). In the presence of TNF/ zVAD-fmk, numerous U937 cells had smaller nuclei with altered morphology, i.e. condensed chromatin, yet chromatin breakup was not observed. This result differs from that reported for TNF induced L929 necrosis where cells die with an unaltered nuclear morphology. ${ }^{1}$ TNF treated U937 cells undergo plasma membrane blebbing with a classical apoptotic appearance and inclusion of zVAD-fmk eliminated this blebbing. Thus TNF/zVAD-fmk induced U937 cell death was characterized by chromatin condensation, but without blebbing, extensive nuclear fragmentation or DNA cleavage to the nucleosomal level.

Translocation of phosphatidylserine was measured by annexin $\mathrm{V}$ binding in parallel with a determination of the loss of membrane permeability as revealed by 7-AAD uptake. Typically early apoptotic cells are defined as having externalized phosphatidylserine with retention of membrane integrity, although even these cells will eventually lose membrane integrity and become annexin V/7-AAD double positive. Necrotic cells, generated by ethanol treatment, are also annexin V/7-AAD double positive (not shown). Examination of these five events revealed five different patterns of cell death (Figure 4). A small increase in the number of single positive annexin $\mathrm{V}$ cells was observed following IFN $-\gamma$ treatment of HT29 cells and double positive cells were absent (Figure 4). With combined TNF/IFN- $\gamma$ treatment, most annexin- $\mathrm{V}$ positive cells also stained with 7-AAD indicating that death was primarily necrotic by this criterion. While all three adherent lines, i.e. HT29, L929 and WEHI-164 cells exhibited similar necrotic patterns of annexin- $V$ staining, the addition of $z V A D-f m k$ led to three different results. Annexin V staining on HT29 cells was unaltered, the display of annexin- $\mathrm{V}$ on WEHI-164 cells was completely blocked and, as expected, annexin- $V$ staining of L929 cells was dependent on zVAD-fmk treatment. The low level of early apoptotic cells in the TNF treated WEHI-164 cells was surprising and no increase in their numbers was found even at very early time points. While the stress of detachment of early apoptotic HT29 cells from the plastic could lead to 7AAD uptake and a loss of annexin- $V$ single positive cells, L929 and WEHI cells are very easily released and less likely to undergo rupturing. In contrast to L929 death, TNF/ZVAD-fmk treated U937 cells exhibited an increased population of annexin- $V$ positive, 7-AAD negative cells when compared to TNF treatment alone (Figure 4). Staurosporine induces apoptosis and staurosporine-treated Jurkat and U937 cells exhibited the same levels of phosphatidylserine exposure as seen with anti-Fas treated Jurkat or TNF/ZVAD-fmk treated U937 cells (data not shown). Therefore the amount of phosphatidylserine translocation in U937 cells was consistent with an apoptotic event. As expected, the annexin $\mathrm{V}$ single positive population did not appear in Jurkat cells treated with antiFas in the presence of zVAD-fmk. Predominantly annexin V/7-AAD double positive L929 cells were observed at all times which is consistent with a pure necrotic event as described. ${ }^{39}$

Confocal microscopy verified that annexin $\mathrm{V}$ was bound to the plasma membrane surface of both anti-Fas treated 

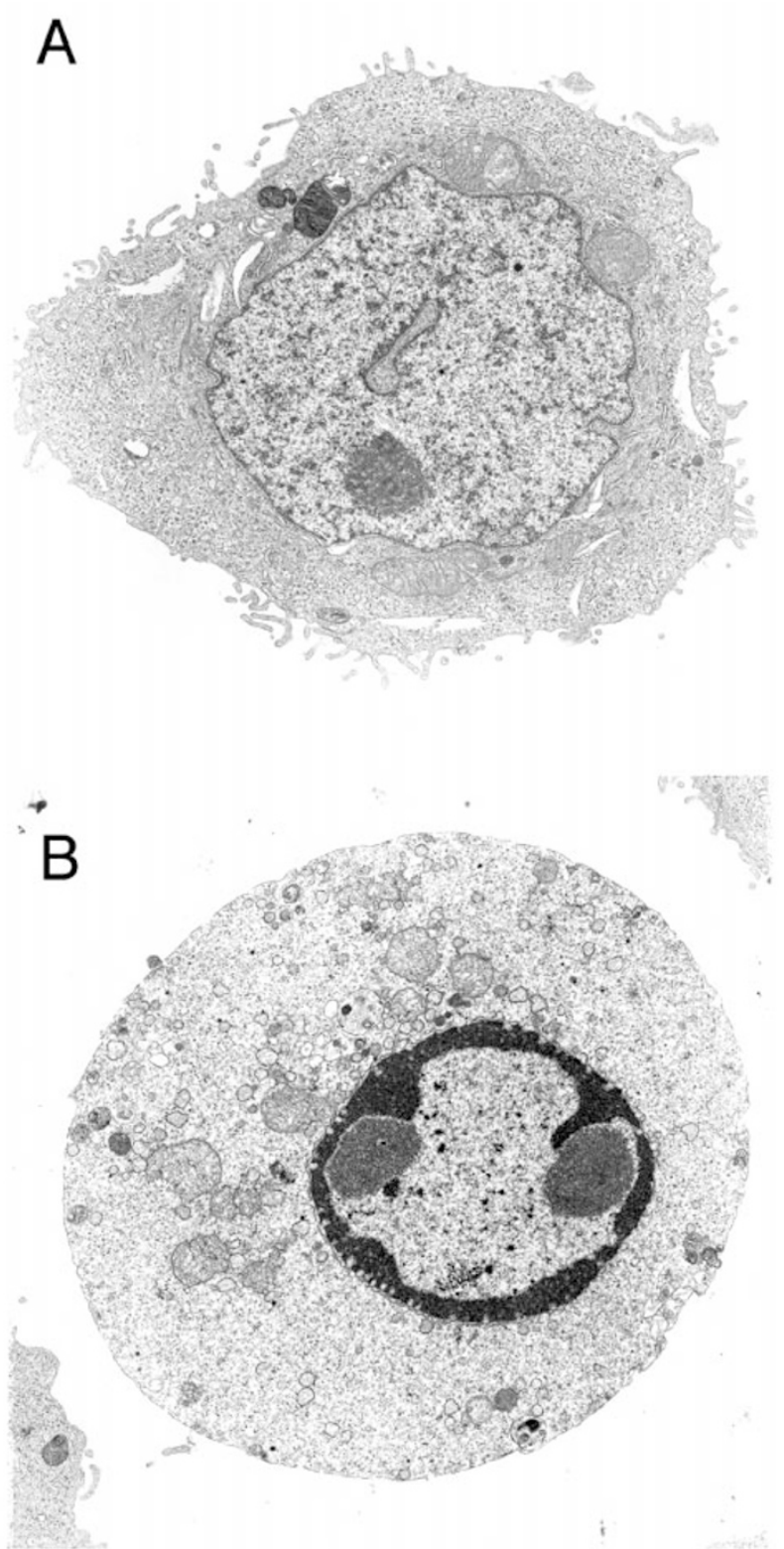

Figure 2 Electron microscopic analysis of the morphology of HT29 cells undergoing anti-Fas induced cell death. (A) Cells treated for $24 \mathrm{~h}$ with IFN- $\gamma$ alone $(80 \mathrm{U} / \mathrm{ml})$. (B) IFN- $\gamma$ plus anti-Fas $\mathrm{mAb}(100 \mathrm{ng} / \mathrm{ml})$

Jurkat cells and TNF/zVAD-fmk treated U937 cells (Figure $5 A, B)$. Annexin $V$ binding to TNF/zVAD-fmk treated L929 cells was localized to intracellular organelles in pattern basically identical to ethanol treated necrotic Jurkat, U939 or L929 cells (Figure 5C-F). Thus both FACS and confocal microscopic analyses confirm that phosphatidylserine externalization accompanies TNF/zVAD-fmk induced U937 death. In contrast to the study by Khwaja et al, ${ }^{6}$ it was reported that the death of U937 cells in response to antiFas, TNF and etoposide treatment was blocked by caspase inhibitors. ${ }^{40,41}$ We have repeated these experiments and confirmed that while zVAD-fmk effectively blocked the DNA fragmentation, the total percentage of annexin $\mathrm{V}$ positive
Table 2 Effects of $z V A D$ on DNA fragmentation following TNFR or Fas activation

\begin{tabular}{|c|c|c|c|c|c|}
\hline \multirow[b]{3}{*}{ Cell } & \multirow{3}{*}{$\begin{array}{c}\text { Receptor } \\
\text { Activated }^{\mathrm{a}}\end{array}$} & \multicolumn{4}{|c|}{ Percentage of cells with subdiploid DNA } \\
\hline & & \multicolumn{4}{|c|}{ +Agonist } \\
\hline & & Hours & Control & $-z V A D$ & +ZVAD \\
\hline \multirow[t]{4}{*}{ Jurkat } & Fas & 3 & 2 & 9 & 2 \\
\hline & & 5 & 7 & 84 & 6 \\
\hline & & 10 & 3 & 45 & 4 \\
\hline & & 15 & 7 & 27 & 6 \\
\hline \multirow[t]{4}{*}{ U937 } & TNFR & 3 & 0 & 0 & 0 \\
\hline & & 5 & 1 & 1 & 0 \\
\hline & & 10 & 1 & 2 & 1 \\
\hline & & 15 & 3 & 20 & 4 \\
\hline \multirow[t]{4}{*}{ L929 } & TNFR & 3 & 1 & 1 & 1 \\
\hline & & 5 & 2 & 2 & 2 \\
\hline & & 10 & 2 & 2 & 1 \\
\hline & & 15 & 3 & 5 & 7 \\
\hline \multirow[t]{3}{*}{ WEHI 164} & TNFR & 5 & 1 & 3 & 4 \\
\hline & & 25 & 2 & 18 & 3 \\
\hline & & 48 & 1 & 51 & 1 \\
\hline \multirow[t]{4}{*}{ HT29 } & TNFR $^{*}$ & 17 & 3 & 2 & 1 \\
\hline & & 41 & 3 & 44 & 7 \\
\hline & $\mathrm{LT} \beta \mathrm{R}$ & 17 & 3 & 3 & 1 \\
\hline & & 41 & 3 & 15 & 3 \\
\hline
\end{tabular}

${ }^{\mathrm{a}}$ Agonist for Fas was $\mathrm{CH} 11$ anti-Fas, TNF for TNFR and a pentametric form of an anti-LT $\beta$ R agonistic mAb. HT29 experiments were conducted in the presence of $80 \mathrm{U} / \mathrm{ml}$ of IFN- $\gamma$ and the HT29 control values represent cultures with IFN- $\gamma$

cells (including both 7AAD positive and negative) was unaltered following etoposide or anti-Fas treatment (data not shown). Likewise, when U937 cells were examined in a 4 day MTT growth assay, caspase inhibition did not spare the cells from the death or anti-proliferative effects of antiFas or etoposide treatment. Therefore, the death of U937 cells is caspase-independent when triggered by TNF-R, and Fas activation or etoposide.

\section{Collapse of mitochondrial membrane potential and involvement of reactive oxygen species (ROS) in these death events}

To compare these death events in more detail, we directly monitored as a function of time mitochondrial membrane potential, production of reactive oxygen species (ROS), annexin $\mathrm{V}$ binding and 7-AAD uptake as an indicator of the loss of membrane integrity. Decreased mitochondrial membrane potential is observed during apoptosis and is critical for the release of cytochrome $c$. The mitochondrial membrane potential can be quantitated by the loss of DiOC6 fluorescence, although this dye does monitor both plasma membrane and mitochondrial membrane potential. ${ }^{42,43}$ Increased production of ROS has been implicated in other caspase-independent death events and can be detected in a FACS analysis by increased cellular staining with dihydroethidium. ${ }^{44}$ As indicated from the study of annexin $\mathrm{V}$ binding, the five patterns of cell death were clearly different (Figure 6). As expected for the prototypical apoptotic event, the appearance of annexin $\mathrm{V}$ positive Jurkat cells paralleled the loss of mitochondrial potential and increased ROS production. Loss of Jurkat plasma membrane integrity lagged about $8 \mathrm{~h}$ behind the other changes. In contrast, annexin $\mathrm{V}$ single positive 


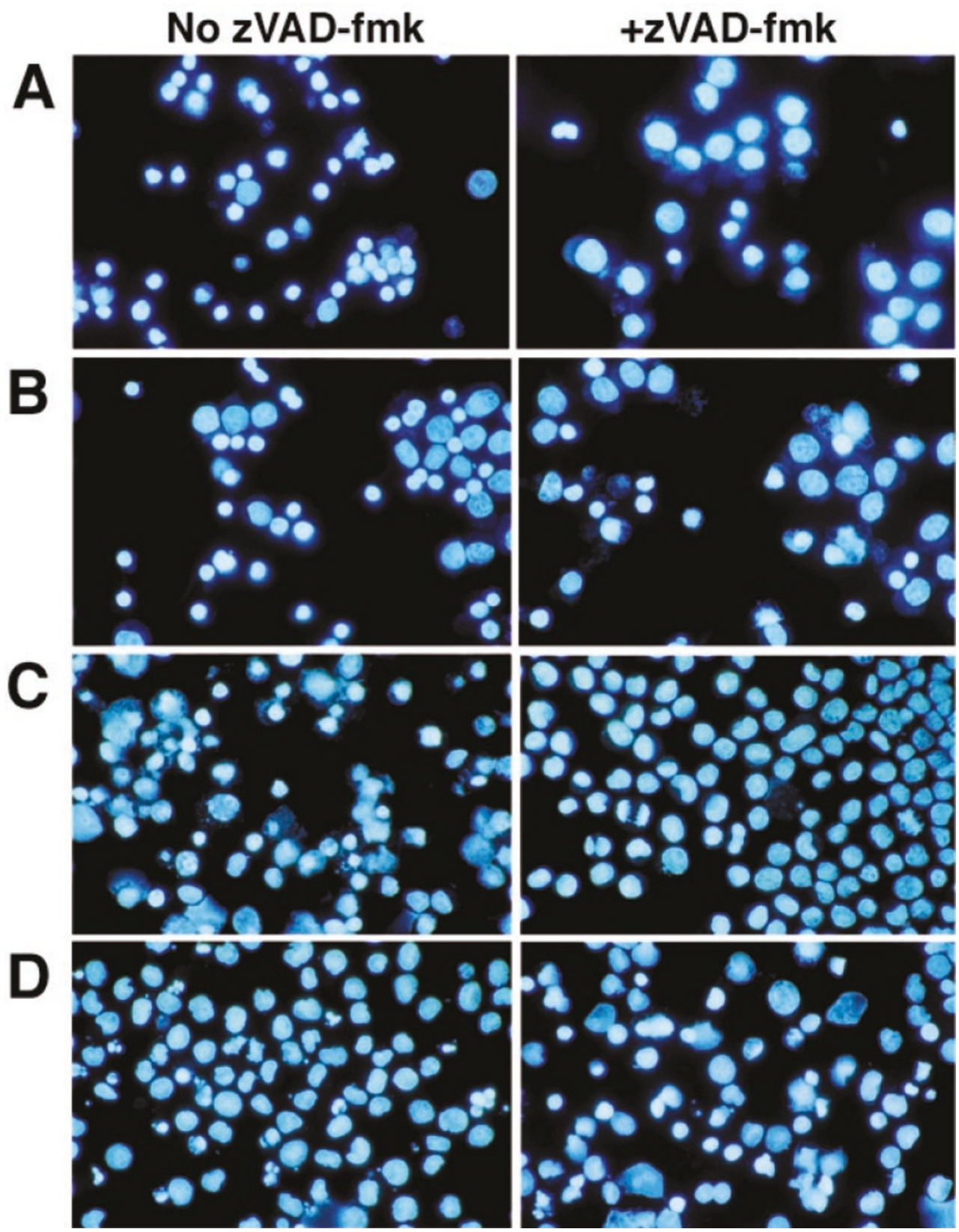

Figure 3 Analysis of the effects of zVAD-fmk $(50 \mu \mathrm{M})$ on chromatin condensation following TNF family receptor activation. HT29 cells were treated $48 \mathrm{~h}$ with antiFas $\mathrm{mAb}$ in $(\mathbf{A})$ or TNF $(20 \mathrm{ng} / \mathrm{ml})$ (B). WEHI-164 cells were treated for $24 \mathrm{~h}$ with murine LT $\alpha / \beta$ in (C) and U937 cells were exposed to TNF (10 ng/ml) for $24 \mathrm{~h}$ in (D). DAPI staining of the nuclei shows large normal nuclei or small condensed nuclei. Some mitotic figures are present in panel C (+zVAD-fmk). Magnification was $630 \times$

staining of U937 cells treated with TNF/zVAD-fmk preceded the loss of mitochondrial membrane potential and membrane integrity and only very low levels of ROS were produced. TNF/ ZVAD-fmk treated L929 cells quickly produced high levels of ROS and lost membrane integrity in the complete absence of annexin $\mathrm{V}$ binding. This result is consistent with prior descriptions of a relatively pure necrotic event. TNF treated WEHI-164 cells did not make detectable levels of ROS yet lost both mitochondrial membrane potential and membrane integrity at the same time. Caspase inhibition blocked all changes in WEHI-164 except for some decrease in mitochondrial membrane potential, but pre-treatment with zVAD-fmk completely blocked the membrane potential change (data not shown). Like L929 cells, HT29 cells produced ROS in parallel with decreased membrane potential and the loss of membrane integrity, but the entire process occurred more slowly. In contrast to L929 cells, this induction was not dependent on the inhibition of caspase activity. Activation of LT $\beta$ R in HT29 cells in the presence of IFN- $\gamma$ showed a similar pattern (not shown). From this analysis it is clear that the death of HT29 cells was not appreciably slowed by caspase inhibition. Similar results were obtained in an 

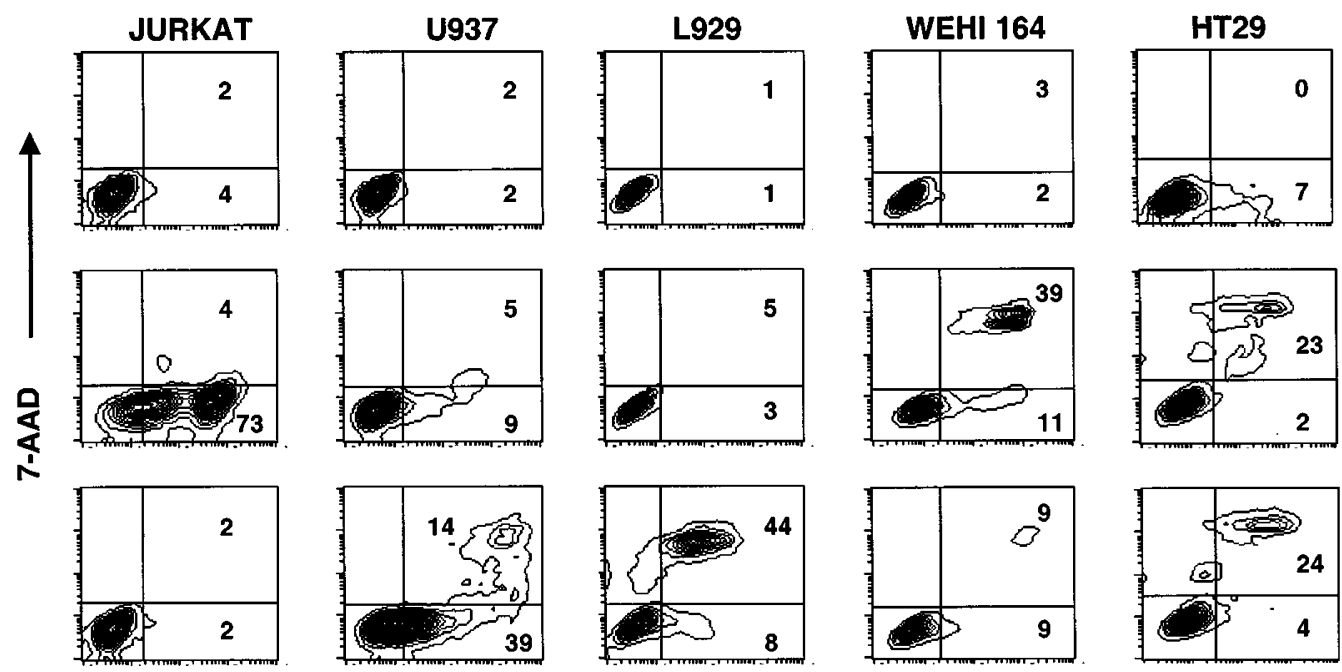

Untreated
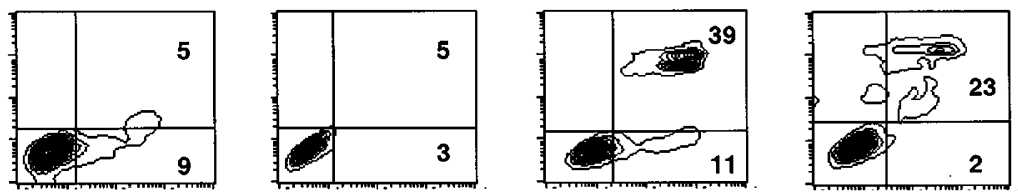

Anti-Fas or TNF
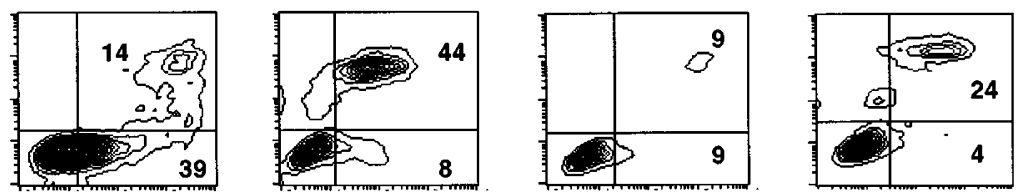

Anti-Fas or TNF + ZVAD

Annexin V

Figure 4 Annexin V binding defines different patterns of cell death in the Jurkat, U937, L929, WEHI 164 and HT29 systems. FACS analysis of FITC-annexin V binding to cells that were counterstained with 7-AAD to indicate loss of cell integrity. Cells were analyzed at $5 \mathrm{~h}$ post addition of anti-Fas (Jurkat), $5 \mathrm{~h}$ post addition of TNF for U937, L929 and WEHI 164 cells and at $27 \mathrm{~h}$ for HT29 cells. All agonists were present at $50 \mathrm{ng} / \mathrm{ml}$ and zVAD-fmk was at $50 \mathrm{nM}$. Numbers indicate the percentage of cells with the indicated gate. The cells in all three HT29 panels were treated with $80 \mathrm{U} / \mathrm{ml}$ of IFN- $\gamma$ and control cells without IFN- $\gamma$ had 2 and $1 \%$ of the cells in the double and single positive annexin $\mathrm{V}$ quadrants respectively

analysis of changes in the rate of acidification of the extracellular medium performed in real time using a

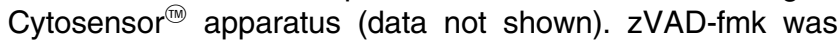
found to delay TNF induced changes in proton fluxing by $5-$ $6 \mathrm{~h}$ in HT29 cells yet the final outcome was not altered. Therefore, using two different techniques to monitor the kinetics of the death process, we find that the death in HT29 cells is only slightly slowed in the absence of caspase activity. These observations describe five phenotypically different forms of death in response to TNF receptor family activation. The TNF/IFN- $\gamma$-HT29, TNF-WEHI-164 and TNF/ZVAD-U937 deaths appear to be mixed forms with elements of both necrotic and apoptotic processes.

\section{Discussion}

The presence of a death domain in a TNF type receptor is generally considered to be indicative of the potential to induce death. However, a number of TNFR family members lacking canonical death domains can trigger death in in vitro settings. Here we have studied TNF family triggered events in the HT29 colon epithelial tumor line in the absence of RNA or protein synthesis inhibitors and without overexpression of any transfected genes. These results document that this cell line dies in response to signaling through the TNF, TRAIL, Fas, TWEAK and $L T \beta$ receptors in the absence of caspase activity. Second, the induced expression of a bona fide death signaling ligand like TNF does not account for death following LT $\beta$ R activation in both HT29 and WEHI 164 cells. Thus activation of $\mathrm{LT} \beta \mathrm{R}$ and most likely the TWEAK receptor can directly induce death in the absence of a death domain. Third, HT29 cell death displays characteristics of both apoptosis and necrosis and appears to be distinct from the other reference death events analyzed in this study.
The ability of death domain-less TNF family receptors to trigger cell death has been enigmatic. The death accompanying activation of TNFRII, LT $\beta$ R, CD27, CD30, CD40 and Taj falls into this group. In the case of TNFRII, some in vivo evidence linked this receptor to death events. $^{7,15,20,24,25,45-51}$ It was reported that TNFRII or TWEAK receptor activation in the rhabdomyosarcoma line KYM-1 induced membrane TNF expression which then triggered cell death in a classical manner via TNFRI activation. $^{7,8}$ This observation was extended to the death of two cell lines overexpressing CD40 and partially to CD30 activation in the lymphoma derived Karpas-299 line. Therefore there was a potential explanation for this enigma that did not involve coupling of nondeath-domain receptors to the death machinery. It was noted that not all death following CD30 activation was accounted for by this mechanism. ${ }^{7}$ In principle, the relatively slow nature of HT29 death would be consistent with a secondary mechanism, yet our previous observations with TWEAK indicated that HT29 death does not involve induction of TNF or FasL expression. ${ }^{20}$ Similarily, neither TNF, FasL nor TRAIL inhibitors affected LIGHT induced HT29 death. ${ }^{21}$ Fn14 has been shown to be a specific high affinity receptor for TWEAK and it lacks a death domain. ${ }^{52}$ The lack of induction of a secondary ligand is consistent with the concept that there is a novel TNF family triggered death pathway in some cells. There are a couple of caveats to this conclusion. Induced-ligand receptor interactions and signaling could occur during protein synthesis and therefore would remain inaccessible to exogenously added blocking agents. It is quite difficult to completely exclude such internal signaling and likewise the existence of additional unknown ligands. Even if such secondary mechanisms are operative, HT29 death remains caspase-independent in- 

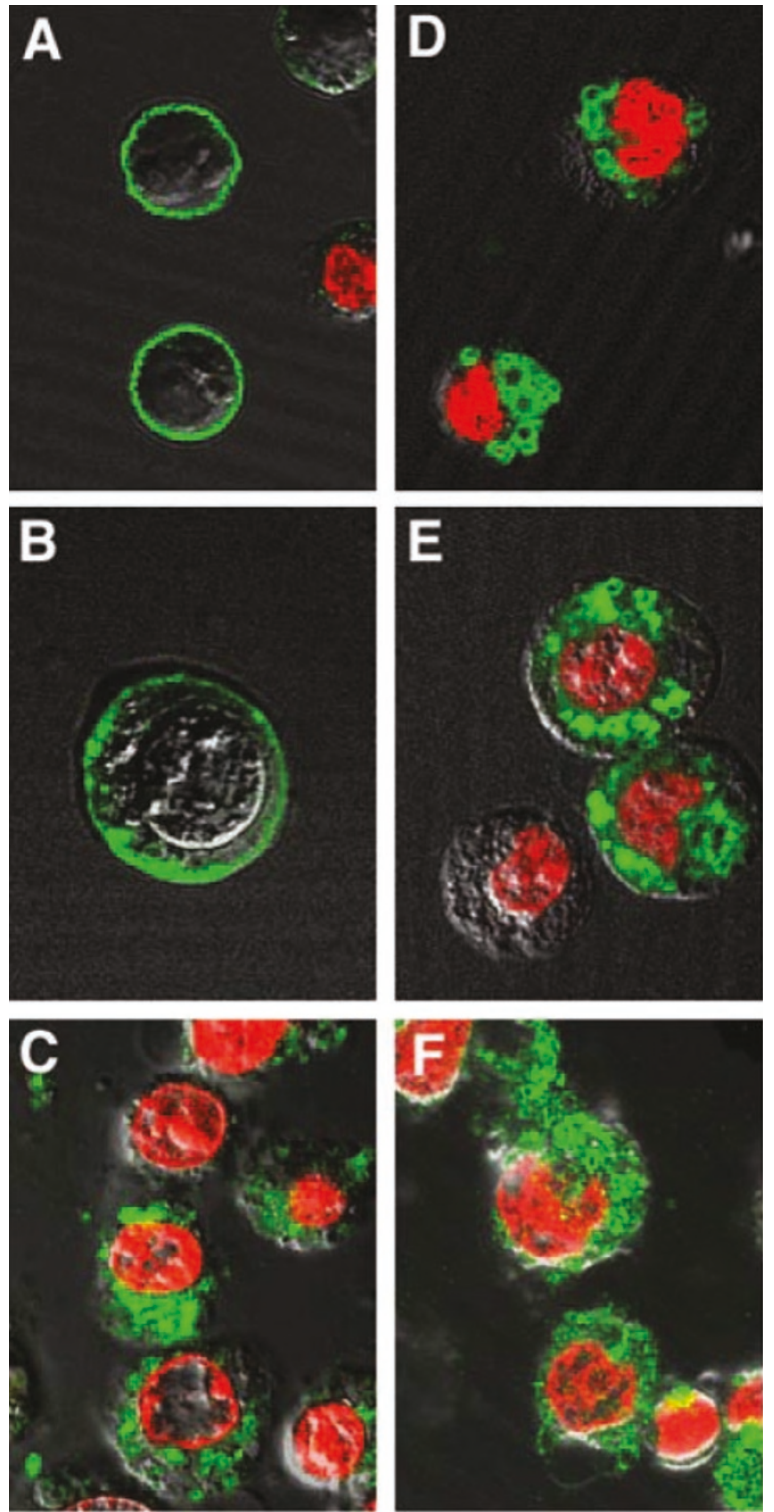

Figure 5 Anexin $\mathrm{V}$ binding to TNF/zVAD-fmk treated U937 and anti-Fas treated Jurkat cells reveals a similar apoptotic pattern. Cells were treated as defined in Figure 4, labeled with Alexa 488 annexinV (green) and propidium iodide (red) following $5 \mathrm{~h}$ exposure to the agonists and visualized by confocal microscopy: (A). anti-Fas treated Jurkat cells, (B). TNF/zVAD-fmk treated U937, (C). TNF/zVAD-fmk treated L929 and ethanol induced necrotic controls (D). Jurkat, (E). U937 and (F). L929 cells. A differential interference contrast image is overlaid in the background

dicating that there are other routes to cell death. Likewise, one can question the validity of using a chemical caspase inhibitor to define caspase independence; however, all the caspases known to couple TNF family receptors to downstream signal transduction machinery are zVAD sensitive. We cannot exclude the involvement of further unknown zVAD resistant caspases although it is likely that most caspases are now known and except for caspase-2, all are zVAD-fmk sensitive. Similar logic would apply to the use of cells transfected with crmA type protease inhibitors.

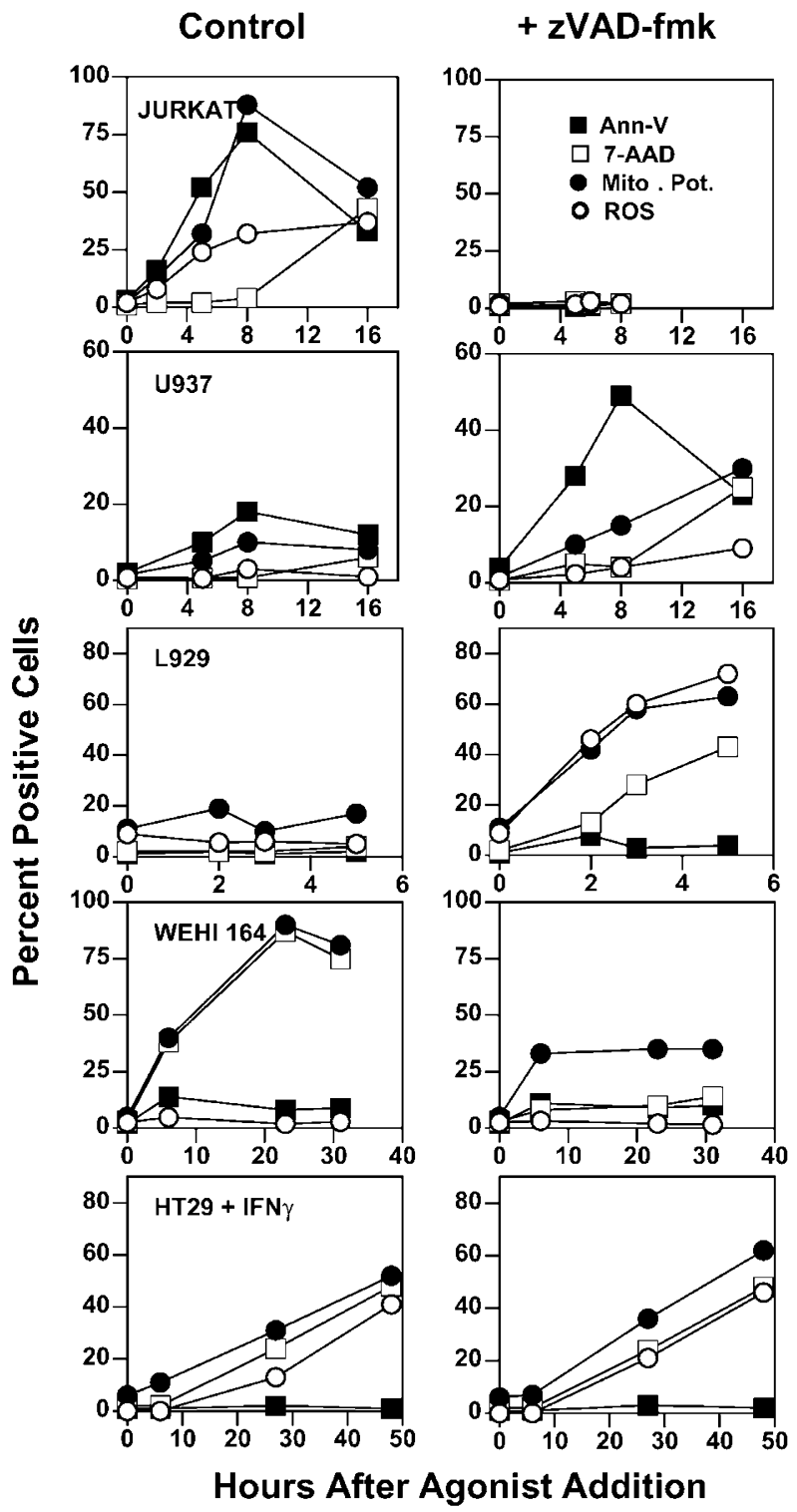

Figure 6 Time course comparison of increased annexin-V binding, loss of mitochondrial membrane potential, ROS generation and increased cell permeability as determined by FACS analysis. From top to bottom, anti-FAS treated Jurkat, TNF treated U937, L929 and WEHI-164 and TNF/IFN- $\gamma$ treated HT2 9 cells in the absence and presence of $100 \mathrm{nM}$ zVAD-fmk. Compared are single positive annexin $\mathrm{V}$ binding (filled square), percentage of cells with decreased $\mathrm{DiOC}_{6}$ fluorescence as an indicator of decreased mitochondrial membrane potential (filled circle), percentage of cells with increased dihydroethidium fluorescence as a monitor of ROS production (open circle) and the 7-AAD fluorescence showing the loss of membrane integrity (open square)

The death of the exquisitely sensitive WEHI 164 fibroblastoid line following LT $\beta$ R activation was blocked by an anti-LT $\beta \mathrm{R} \mathrm{mAb}$, but not by mTNFRI-Ig ${ }^{24}$ and this work further excludes mFasL, MTRIAL and mTWEAK induction as a component of that activity. Based on this singular and rather complex system involving a heteromeric ligand, a death domain-less receptor appears to be able to couple to 
caspase-mediated events. Direct coupling at the receptor level would be unlikely and the observation probably reflects engagement of downstream effector caspases. Similar caspase-dependent induction of apoptosis was triggered by the death-domainless TNFRII following supraoptimal antigen stimulation of the TCR and also accompanied overexpression of CD30 and LT $\beta \mathrm{R}^{51,53,54}$ These observations substantiate the premise that the death-domainless receptors can initiate death events without proximal caspase involvement.

An emerging concept is that in some settings, TNFR family members induce an apoptotic death; however, the death becomes necrotic in the absence of functional caspases. ${ }^{1,4-6,57,58}$ In HT29 cells, receptors in the TNF family trigger a death with features of both apoptosis and necrosis. The observations of chromatin condensation and margination, loss of microvilli, detachment and rounding are indicative of apoptotic events yet cytoplasmic shrinkage was not observed with HT29 cells. The observed organellefree clear cytoplasmic blebs are probably more indicative of necrosis. Moreover, we did not observe an appreciable number of early phase apoptotic HT29 cells with annexin V binding as was the case with TNF/zVAD induced necrotic death of L929 cells. Since chromatin condensation occurred, this death differs from autophagic death which is not accompanied by changes in nuclear morphology. ${ }^{11}$ We conclude that the death of HT29 cells triggered by receptors in the TNF family is a mixed form with features of both necrosis and apoptosis and fits most closely the apoptosis-like PCD described by Leist et al. ${ }^{9}$ A previous study defined the HT29 death as caspase-dependent and this conclusion was reached from the quantitation of histone associated DNA fragments which correlate with nucleosome release following simultaneous exposure to rather high levels of TNF, IL-1 and IFN- $\gamma .{ }^{35}$ While caspase inhibition can slow TNFR and Fas triggered HT29 death and nucleosomal cleavage will be prevented, the cells still die. Many studies have relied on inhibition of DNA fragmentation as the readout of apoptosis, yet this linkage does not necessarily reflect the survival outcome. This work shows that these events are clearly coupled in Jurkat and WEHI 164 cells, but in HT29 and U937 cells, using fragmentation as a surrogate marker for death leads to an erroneous conclusion. HT29 death may result from engagement of several death effector mechanisms. It is also possible that following TNFR, Fas or TRAIL-R activation, two or more pro-death mechanisms are engaged, one of which is caspase-mediated and a second pathway which is revealed in the presence of caspase inhibition.

To properly characterize the HT29 death event, we used anti-Fas treated Jurkat and TNF/zVAD-fmk treated L929 cells as reference points for prototypical apoptotic and necrotic events. TNF/VAD induced U937 death was also investigated in some depth given its unusual nature along with the exquisitely sensitive WEHI-164 murine fibroblast line. ${ }^{6}$ A summary of the properties of the various death events analyzed here is presented in Table 3 . Analysis of loss of mitochondrial potential, chromatin cleavage and condensation, annexin $\mathrm{V}$ binding, ROS production and zVAD sensitivity revealed that the five death events were quite different. This heterogeneity of death types was surprising and it was difficult to find unifying features. Only the potentiation of TNF induced death by zVAD in NIH3T3, L929 and U937 cells suggested a common mechanism. The recent description of alternate Fas signaling depending on whether a caspase or FLIP serves as the primary adaptor may provide some molecular rationale for the potentiating effects of caspase inhibitors in some systems. ${ }^{57}$ The U937 and L929 systems are also similar in outcome, yet differ substantially. The translocation of phosphatidylserine in dying U937 cells clearly demarcates this event from L929 necrosis. Curiously, we could not find many early apoptotic cells when death was induced in cells of nonhematapoietic lineage, which also happened to be adherent cell lines, yet such cells were readily observed in the suspended U937 and Jurkat systems. It is unclear if this is a generalizable observation given that only a few cells from each lineage were examined here. Likewise, membrane damage accompanying the removal of dying

Table 3 Summary of the death events induced by TNF family signaling in five cell types

\begin{tabular}{|c|c|c|c|c|c|c|}
\hline \multirow[b]{2}{*}{ Cell } & \multirow{2}{*}{$\begin{array}{l}\text { Receptor } \\
\text { activated }\end{array}$} & \multicolumn{2}{|c|}{ Chromatin } & \multirow[b]{2}{*}{$A-V^{b}$} & \multirow[b]{2}{*}{ ROS } & \multirow[b]{2}{*}{ Type of death } \\
\hline & & Condensation & Fragmentation & & & \\
\hline \multirow[t]{2}{*}{ Jurkat } & FAS & + & +++ & +++ & ++ & Apoptosis \\
\hline & FAS+zVAD & - & - & - & - & No death \\
\hline \multirow[t]{2}{*}{ U937 } & TNFR & $+1-$ & + & $+1-$ & - & Apoptosis \\
\hline & TNFR+zVAD & + & $+1-$ & ++ & + & Mixed? \\
\hline \multirow[t]{2}{*}{ L929 } & TNFR & - & - & - & - & Little death \\
\hline & TNFR+zVAD & - & - & - & +++ & Necrosis \\
\hline \multirow[t]{4}{*}{ WEHI 164} & TNFR & + & ++ & + & - & Apoptosis \\
\hline & TNFR+zVAD & - & - & - & - & No death \\
\hline & $\mathrm{LT} \beta \mathrm{R}$ & + & ++ & + & - & Apoptosis \\
\hline & $\mathrm{LT} \beta \mathrm{R}+\mathrm{zVAD}$ & - & - & - & - & No death \\
\hline \multirow[t]{4}{*}{ HT29 } & $\mathrm{TNF}^{\mathrm{a}}$ & + & ++ & $+1-$ & ++ & Mixed \\
\hline & TNF+zVAD & + & - & $+1-$ & ++ & Mixed \\
\hline & $\mathrm{LT} \beta \mathrm{R}$ & + & ++ & $+1-$ & ++ & Mixed \\
\hline & $\mathrm{LT} \beta \mathrm{R}+\mathrm{zVAD}$ & + & - & $+1-$ & ++ & Mixed \\
\hline
\end{tabular}

aSimilar data for activation of each of the following receptors, TNFR, Fas, TWEAK-R, TRAIL-R and LT $\beta R$. ${ }^{b}$ Annexin $V$ positive, 7AAD negative early apoptotic cells 
cells from plastic may mask the existence of early apoptotic cells. Our attempts to prestain or remove the cells with trypsin without EDTA-induced trauma did not result in enhanced detection of annexin $\mathrm{V}$ single positive adherent cells (data not shown). Likewise in HT29 and U937 cells, we observed chromatin condensation without DNA fragmentation indicating that chromatin condensation is a separate event independent of caspase activation, a conclusion reached by others. ${ }^{58}$ This observation may also be consistent with DNA cleavage down to $50 \mathrm{~kb}$ fragments being critical for condensation since this event is mediated by AIF and/or Acinus which can be activated independently of caspase activity. ${ }^{58,59}$ This level of chromatin condensation may be part of an apoptotic program or it may be linked to cell cycle events and mitotic catastrophe. In contrast, chromatin fragmentation and condensation appeared to be coupled in Jurkat and WEHI-164 cells. Therefore using the Jurkat and L929 systems as examples of pure apoptosis and necrosis, the TNF-HT29, TNF/ZVADU937 and TNF-WEHI 164 deaths were mixed with varying degrees of apoptotic and necrotic features. These results suggest that TNF receptor family members can engage various components of the death machinery selectively, leading to the various death phenotypes described here.

Reactive nitrogen species and ROS generation probably play central roles in many death processes and the TNF/ ZVAD treated L929 cases may be a good example. ${ }^{1}$ In HT29 cells, ROS production was significant and paralleled the loss of membrane potential. Attempts to protect HT29 cells from death with antioxidants have not been successful in our hands. Others have noted that agents such as butylated hydroxyanisole only poorly protect cells from late phase ROS components and, moreover, it is unclear whether these ROS indicator dyes such as dihydrorhodamine or dihydroethidium report faithfully on all ROS forms. ${ }^{60}$ A novel fullerine based antioxidant was noted to block HT29 death following LT $\beta$ R activation by the ligand LIGHT which is supportive of an ROS based component. ${ }^{61}$ Involvement of reactive nitrogen intermediates and ceramide have not been implicated and we also have not been able to demonstrate any involvement of these mediators. ${ }^{35,62}$ ROS production was observed in TNF/zVAD treated NIH3T3 cells, yet was not reported for U937 cells. ${ }^{6}$ In our U937 experiments we did not detect levels of ROS production comparable to the L929 or HT29 systems. While U937 ROS was slightly augmented by caspase inhibition, this increase only occurred after cells had begun to lose membrane integrity. When coupled with the differences in phosphatidylserine translocation, it is possible that the U937 death mechanism is fundamentally different from that engaged in HT29, L929 and NIH3T3 cells. Given the commonality of ROS induction, it would be attractive to group mechanistically the HT29, L929 and NIH 3T3 events. This step may be premature. First, the apparently mixed apoptotic/necrotic HT29 death is not dramatically potentiated by caspase inhibition. Secondly, the HT29 death is relatively slow and the requirement for IFN- $\gamma$ is unique. Lastly, the ability of zVAD-fmk to potentiate death is limited to the TNF receptor in L929 and U937 cells, e.g. TRAIL-R or LT $\beta$ R activation was not potentiated in U937 cells. In contrast, this death pathway in HT29 cells can be generically triggered by probably all TNF family receptors present on these cells.

An analysis of the signal transduction pathways involved in HT29 death was not within the scope of this work and this area remains undefined. Earlier RNA based work had noted that IFN- $\gamma$ upregulated caspase expression in HT29 cells, yet here we have shown that caspases at most simply accelerate the HT29 death. ${ }^{19}$ Moreover, in this study and in another report, the increase in caspase activity was very small compared to that occurring in both U937 and Jurkat cells. $^{35}$ Theoretically, one needs to invoke the involvement of a p53 independent pathway that can be commonly accessed by many TNF family receptors. Potential candidates include linkage to bcl-2 family members, phospholipases A2, PML induction or the stress activated protein kinases and these events are then coupled in some manner to AIF release and ROS generation. ${ }^{63,64}$ cJun $\mathrm{N}$ terminal kinase (JNK), ERK and p38 kinase are activated by many TNF family receptors both with and without death domains often independently of caspase activation $^{57,65}$ (including LT $\beta$ R, M Lukashev and M Jarpe, unpublished observations). TRAF adaptors have been suggested to link LT $\beta$ R to HT29 death and are potentially involved in linking this receptor to $\mathrm{NF} \kappa \mathrm{B} \gamma$ inducing kinase. ${ }^{6,67}$ Mitochondrial AIF release is an attractive candidate to account for these observations and the receptor may be coupled to the mitochondria via effects on bcl-2 family members or via kinase activation. Interestingly, both the morphology and the caspase-independence of the HT29 death event resemble the death of tumor cells following depletion of Hsp70.68 Moreover, Hsp70 overexpression has been shown to block AIF induced apoptosis suggesting some parallels in these observations. ${ }^{69}$

We have shown here that TNFR family members can trigger HT29 death via a caspase-independent pathway regardless of the presence or absence of a death domain in the receptor. This death displays aspects of both apoptotic and necrosis. Whether these events are physiologically relevant remains unknown; however, the human adenocarcinoma HT29 line is a pluripotent fetal-like epithelial cell representative of many primary colon carcinomas. ${ }^{28}$ The death of HT29 epithelial cells when triggered especially by $\mathrm{LT} \beta \mathrm{R}$ is relatively slow and, while more difficult to study, it may be revealing previously unappreciated behavior. An understanding of these slower death events in epithelial cells may prove useful for the development of novel anticancer approaches. Certainly activation of TNF family receptors lacking death-domains should be evaluated in oncology settings. A better comprehension of how transformation, differentiation, IFN- $\gamma$ signaling and tumor suppressor gene status influences the manner in which a cell interprets signals from the TNF family receptors may help define tumors susceptible to this type of treatment.

\section{Materials and Methods}

\section{Cells and reagents}

The HT29-14 variant of ATCC derived HT29 cells has been described $^{15}$ and the Jurkat, U937 and L929 cells were obtained from 
the ATCC and grown in RPMI 1640 medium with $10 \%$ fetal bovine serum (Hyclone, Logan, UT, USA) and glutamine. The origin and growth of the WEHI 164 line has been described. ${ }^{70}$ zVAD-fmk was obtained from Bachem (Torrence, CA, USA). The following ligands and antibodies were purchased: anti-human Fas mAb CH11 (Kamaya Biomedical Co, Seattle, WA, USA), neutralizing anti-human Fas-L (NOK-1) and anti-murine Fas-L (MLF3) (BD Pharmingen, San Diego, CA, USA), anti-murine TNF neutralizing mAb, MP6-XT3 (Gibco BRL, Gaithersburg, MD, USA), murine TRAIL-flag (Biomol Research Lab, Plymouth Meeting, PA, USA), murine His tagged-Fas ligand and antiHis Tag (R\&D Systems, Minneapolis, MN, USA) human FLAG-Fas ligand (Alexis, San Diego, CA, USA), anti-Flag M2 (Sigma, St. Louis, MO, USA) and FITC labeled annexin V (Pharmingen, San Diego, CA, USA). Human FLAG-TRAIL and human TRAIL-R2-Ig were gifts from Jurg Tschopp. MP6-XT3 had been shown to effectively block murine TNF. ${ }^{24}$ The hamster anti-TWEAK antibody ABD3 was developed at Biogen and effectively blocks both human and murine TWEAKinduced HT29 cell death. ${ }^{71}$ The human IFN- $\gamma$, anti-human TNF mAb $104 \mathrm{c}$, murine and human LT $\beta$ R-Ig fusion proteins, the human and mouse $L T \alpha / \beta$ ligands and the agonist anti-human $L T \beta R$ mAb (CBE11) have been described previously. ${ }^{15,24,72}$

\section{Microscopy}

Electron microscopy was performed on samples that included all the cells, i.e. both the dead cells released from the plastic surface and the remaining adherent cells obtained by trypsinization. Microscopy was performed on thin sections using conventional paraformaldehyde fixation and osmium tetraoxide staining. For fluorescence microscopy, cells were fixed in $2 \%$ paraformaldehyde, cytospun onto slides, fixed in $95 \%$ ethanol and stained with $0.5 \mu \mathrm{g} / \mathrm{ml}$ DAPI. In the confocal microscopy experiments, cells were stained with Alexa-488 annexin V (Molecular Probes, Eugene, OR, USA) as described by the manufacturer and $5 \mu \mathrm{g} / \mathrm{ml}$ propidium iodide.

\section{Cell growth assays}

The growth assays involved plating 3000-5000 cells per 96-well depending on the cell type and viable mitochondria were quantitated with a MTT readout after 3-4 days of growth. These assays have been previously described in detail. ${ }^{20}$ Cells were mixed with $100 \mu \mathrm{M}$ zVAD-fmk for $10 \mathrm{~min}$ prior to dilution into the assay yielding a final concentration of $50 \mu \mathrm{M}$ during the growth phase. zVAD-fmk was dissolved at a stock concentration of $20-100 \mathrm{mM}$ in DMSO and matching solvent concentrations were run as controls in all experiments. The input cell numbers for the long-term growth assays were 5000/well for HT29, Jurkat and U937 cells and 4000/well for WEHI 164. For anti-LT $\beta$ R agonist antibody killing of HT29 cells, serial dilutions of the antibody were captured onto goat anti-mlgGFc-coated 96-well plates $(10 \mu \mathrm{g} / \mathrm{ml})$. In blocking experiments, the following inhibitor concentrations were used: anti-hTNF 104c, MP6-XT3, BBF6 anti-mLT $\beta$, ABD3 anti-h/mTWEAK and anti-hFasL NOK-1 at $5 \mu \mathrm{g} / \mathrm{ml}$, anti-mTNF and MLF3 anti-mFasL at $3 \mu \mathrm{g} / \mathrm{ml}$ and hTRAIL-R2-lg, mTRAIL-R2-lg and hLTBR-Ig at $2 \mu \mathrm{g} / \mathrm{ml}$.

\section{FACS analyses}

L929 cells were removed by EDTA treatment and WEHI-164 and HT29 cells were gently subjected to a mild trypsinization for removal. All floaters were included in the analysis. Cells were resuspended at a concentration of $10^{6} / \mathrm{ml}$ in complete tissue culture media in the presence or absence of $250 \mathrm{ng} / \mathrm{ml}$ anti-Fas $\mathrm{mAb} \mathrm{CH}-11,100 \mathrm{ng} / \mathrm{ml}$ or TNF, $\pm 50 \mu \mathrm{M}$ zVAD-fmk. Following the $5 \mathrm{~h}$ treatment, L929 and WEHI
164 cells were removed again by EDTA and washed once. Jurkat and U937 cells were harvested directly. For determination of annexin V binding and membrane permeability, the cells were resuspended in $50 \mu \mathrm{l}$ of cold RPMI with $10 \%$ FBS, $0.05 \%$ azide and $50 \mu \mathrm{l}$ of $2 \mu \mathrm{g} / \mathrm{ml}$ FITC labeled annexin V in media was added for $30 \mathrm{~min}$ on ice. Cells were then resuspended in $100 \mu \mathrm{l}$ of $10 \mu \mathrm{g} / \mathrm{ml} 7$-amino actinomycin D (7-AAD) in media with azide for another $5 \mathrm{~min}$, washed in media with azide and analyzed in $\mathrm{Ca}^{2+} / \mathrm{Mg}^{2+}$ containing PBS with $5 \% \mathrm{FBS}$ and $0.05 \%$ azide. Cells were placed in $10 \%$ ethanol for $3-5 \mathrm{~h}$ at $37^{\circ} \mathrm{C}$ to provide a positive control for necrosis. ${ }^{73}$ Aliquots of cells at each timepoint were resuspended into hypotonic propidium iodide, left overnight at $4{ }^{\circ} \mathrm{C}$ and analyzed for DNA fragmentation by conventional FACS methods. For determination of superoxide production and mitochondrial potential changes following anti-Fas or TNF treatment, $2 \times 10^{5}$ cells were treated with $250 \mathrm{nM}$ dihydroethidium or $25 \mathrm{nM}$ $\mathrm{DiOC}_{6}$ (Molecular Probes, Eugene, OR, USA) for $40 \mathrm{~min}$ at $37^{\circ} \mathrm{C}$. The cells were washed once and analyzed on a FACS Calibur Instrument using the FL1 and FL3 channels for $\mathrm{DiOC}_{6}$ and dihydroethidium, respectively. The data are presented as percent positive cells which was actually either decreased $\mathrm{DiOC}_{6}$ or increased dihydroethidium staining and only very small cells and debris in the scatter profile were gated out.

\section{Acknowledgements}

We thank Jurg Tschopp for the Flag-TRAIL and TRAIL-R2-Ig preparations, Ya-hui Tu (Whitehead Institute) for the electron microscopy, Holly Prentice for helpful advice, Sukumari Mohan for FACS analysis, Irene Sizing for the blocking TWEAK mAb and Jennifer Gommerman, Tim Zheng and Matvey Lukashev for critical reading and comments.

\section{References}

1. Fiers W, Beyaert R, Declercq W and Vandenabeele P (1999) More than one way to die: apoptosis, necrosis and reactive oxygen damage. Oncogene 18: 77197730

2. Hengartner MO (2000) The biochemistry of apoptosis. Nature 407: 770-776

3. Wallach D, Varfolomeev EE, Malinin NL, Goltsev YV, Kovalenko AV and Boldin MP (1999) Tumor necrosis factor receptor and Fas signaling mechanisms. Annu. Rev. Immunol. 17: 331-367

4. Holler N, Zaru R, Micheau O, Thome M, Attinger A, Valitutti S, Bodmer JL, Schneider P, Seed B and Tschopp J (2000) Fas triggers an alternative, caspase8-independent cell death pathway using the kinase RIP as effector molecule. Nat. Immunol. 1: 489-495

5. Matsumura $H$, Shimizu $Y$, Ohsawa $Y$, Kawahara A, Uchiyama $Y$ and Nagata $S$ (2000) Necrotic death pathway in fas receptor signaling. J. Cell. Biol. 151: 12471256

6. Khwaja A and Tatton L (1999) Resistance to the cytotoxic effects of tumor necrosis factor alpha can be overcome by inhibition of a FADD/caspasedependent signaling pathway. J. Biol. Chem. 274: 36817-36823

7. Grell M, Zimmermann G, Gottfried E, Chen CM, Goenwald U, Huang DC, Lee YH, Duerkop H, Engelmann H, Scheurich P, Wajant H and Strasser A (1999) Induction of cell death by tumour necrosis factor (TNF) receptor 2, CD40 and CD30: a role for TNF-R1 activation by endogenous membrane- anchored TNF. EMBO J. 18: $3034-3043$

8. Schneider P, Schwenzer R, Haas E, Muhlenbeck F, Schubert G, Scheurich P, Tschopp J and Wajant $H$ (1999) TWEAK can induce cell death via endogenous TNF and TNF receptor 1. Eur. J. Immunol. 29: 1785-1792

9. Leist $M$ and Jaattela $M$ (2001) Four deaths and a funeral: from caspases to alternative mechanisms. Nat. Rev. Mol. Cell. Biol. 2: 589-598

10. Kitanaka C and Kuchino Y (1999) Caspase-independent programmed cell death with necrotic morphology. Cell Death Differ. 6: 508-515 
11. Zakerl Z, Bursch W, Tenniswood M and Lockshin RA (1995) Cell death programmed, apoptosis, necrosis or other? Cell Death Diff. 2: 87-96

12. Bidere $N$ and Senik A (2001) Caspase-independent apoptotic pathways in $T$ lymphocytes: a minireview. Apoptosis 6: $371-375$

13. Margot T and TschoppJ (2001) Regulation of lymphocyte proliferation and death by FLIP. Nature Rev. Immunol. 1: 50-58

14. Joza N, Susin SA, Daugas E, Stanford WL, Cho SK, Li CY, Sasaki T, Elia AJ, Cheng HY, Ravagnan L, Ferri KF, Zamzami N, Wakeham A, Hakem R, Yoshida $\mathrm{H}$, Kong YY, Mak TW, Zuniga-Pflucker JC, Kroemer G and Penninger JM (2001) Essential role of the mitochondrial apoptosis-inducing factor in programmed cel death. Nature 410: $549-554$

15. Browning JL, Miatkowski K, Sizing I, Griffiths D, Zafari M, Benjamin CD, Meier W and Mackay F (1996) Signaling through the lymphotoxin beta receptor induces the death of some adenocarcinoma tumor lines. J. Exp. Med. 183: 867-878

16. Browning $J$ and Ribolini A (1989) Studies on the differing effects of tumor necrosis factor and lymphotoxin on the growth of several human tumor lines. J. Immunol. 143: 1859-1867

17. Yonehara S, Ishii A and Yonehara M (1989) A cell-killing monoclonal antibody (Anti-fas) to a cell surface antigen co-downregulated with the receptor of tumor necrosis factor. J. Exp. Med. 169: 1747-1756

18. Abreu-Martin MT, Vidrich A, Lynch DH and Targan SR (1995) Divergent induction of apoptosis and IL-8 secretion in HT-29 cells in response to TNF- $\alpha$ and ligation of Fas ligand. J. Immunol. 155: 4147-4154

19. Ossina NK, Cannas A, Powers VC, Fitzpatrick PA, Knight JD, Gilbert JR Shekhtman EM, Tomei LD, Umansky SR and Kiefer MC (1997) Interferongamma modulates a p53-independent apoptotic pathway and apoptosis-related gene expression. J. Biol. Chem. 272: 16351-16357

20. Chicheportiche Y, Bourdon PR, Xu H, Hsu YM, Scott H, Hession C, Garcia I and Browning JL (1997) TWEAK, a new secreted ligand in the tumor necrosis factor family that weakly induces apoptosis. J. Biol. Chem. 272: 32401-32410

21. Rooney IA, Butrovich KD, Glass AA, Borboroglu S, Benedict CA, Whitbeck JC Cohen GH, Eisenberg RJ and Ware CF (2000) The lymphotoxin-beta receptor is necessary and sufficient for LIGHT-mediated apoptosis of tumor cells. J. Biol. Chem. 275: 14307-14315

22. Sugarman BJ, Aggarwal BB, Hass PE, Figari IS, Palladino Jr MA and Shepard HM (1985) Recombinant human tumor necrosis factor-alpha: effects on proliferation of normal and transformed cells in vitro. Science 230: 943-945

23. Fiers W, Brouckaert P, Devos R, Fransen L, Leroux-Roels G, Remaut E, Suffys P, Tavernier J, Van der Heyden J and Van Roy F (1986) Cold Spring Harbor Symp. Quant. Biol. 51: 587-595

24. Mackay F, Bourdon PR, Griffiths DA, Lawton P, Zafari M, Sizing ID, MiatkowskiK Ngam-ek A, Benjamin CD, Hession C, Ambrose CM, Meier W and Browning JL (1997) Cytotoxic activities of recombinant soluble murine lymphotoxin-alpha and lymphotoxin-alpha beta complexes. J. Immunol. 159: 3299-3310

25. Eby MT, Jasmin A, Kumar A, Sharma K and Chaudhary PM (2000) TAJ, a nove member of the tumor necrosis factor receptor family, activates the c-Jun $\mathrm{N}$ terminal kinase pathway and mediates caspase-independent cell death. J. Biol. Chem. 275: 15336-15342

26. Kanda H, Igaki T, Kanuka H, Yagi T and Miura M (2002) Wenger, a member of the drosophila TNF receptor superfamily, is required for Eiger signaling. J. Biol. Chem. 277: 28372-28375

27. Sarin A, Williams MS, Alexander-Miller MA, Berzofsky JA, Zacharchuk CM and Henkart PA (1997) Target cell lysis by CTL granule exocytosis is independent of ICE/Ced-3 family proteases. Immunity 6: 209-215

28. Huet C, Sahuquillo-Merino C, Coudrier E and. Louvard D (1987) Absorptive and mucus-secreting subclones isolated from a multipotent intestinal cell line (HT29) provide new models for cell polarity and terminal differentiation. J. Cell. Biol. 105: $345-357$

29. Velcich A, Palumbo L, Jarry A, Laboisse C, Racevskis J and Augenlicht L (1995) Patterns of expression of lineage-specific markers during the in vitro- induced differentiation of HT29 colon carcinoma cells. Cell Growth Differ. 6: 749-757

30. VanArsdale TL and Ware CF (1994) TNF receptor signal transduction. Liganddependent stimulation of a serine protein kinase activity associated with (CD120a) TNFR60. J. Immunol. 153: 3043-3050

31. Vercammen D, Brouckaert G, Denecker G, Van de Craen M, Declercq W, Fiers W and Vandenabeele $P$ (1998) Dual signaling of the Fas receptor: initiation of both apoptotic and necrotic cell death pathways. J. Exp. Med. 188: 919-930

32. Nicholson DW (1999) Caspase structure, proteolytic substrates, and function during apoptotic cell death. Cell Death Differ. 6: 1028-1042
33. Degli-Esposti MA, Davis-Smith T, Din WS, Smolak PJ, Goodwin RG and Smith CA (1997) Activation of the lymphotoxin beta receptor by cross-linking induces chemokine production and growth arrest in A375 melanoma cells. J. Immunol. 158: $1756-1762$

34. OberhammerF, Wilson JW, Dive C, Morris ID, Hickman JA, Wakeling AE, Walker PR and Sikorska M (1993) Apoptotic death in epithelial cells: cleavage of DNA to $300 \mathrm{and} / \mathrm{or} 50 \mathrm{~kb}$ fragments prior to or in the absence of internucleosomal fragmentation. EMBO J. 12: 3679-3684

35. WrightK, Kolios G, Westwick J and Ward SG (1999) Cytokine-induced apoptosis in epithelial HT-29 cells is independent of nitric oxide formation. Evidence for an interleukin-13-driven phosphatidylinositol 3-kinase-dependent survival mechanism. J. Biol. Chem. 274: 17193-17201

36. Dusenbury CE, Davis MA, Lawrence TS and Maybaum J (1991) Induction of megabase DNA fragments by 5 -fluorodeoxyuridine in human colorectal tumor (HT29) cells. Mol. Pharmacol. 39: 285-289

37. Dealtry GB, Naylor MS, Fiers W and Balkwill FR (1987) DNA fragmentation and cytotoxicity caused by tumor necrosis factor is enhanced by interferon-gamma. Eur. J. Immunol. 17:689-693

38. Tamura T, Aoyama N, Saya H, Futami S, Miyamoto M, Koh T, Ariyasu T, Tachi M, Kasugs M and Takahashi R (1995) Induction of Fas-meidated apoptosis in p53transfected human colon carcinoma cells. Oncogene 11: 1939-1946

39. Vercammen D, Vandenabeele P, Beyaert R, Declercq W and Fiers W (1997) Tumour necrosis factor-induced necrosis versus anti-Fas-induced apoptosis in L929 cells. Cytokine 9: $801-808$

40. Mashima T, Naito M, Kataoka S, Kawai H and Tsuruo T (1995) Aspartate-based inhibitor of interleukin-1 beta-converting enzyme prevents antitumor agentinduced apoptosis in human myeloid leukemia U937 cells. Biochem. Biophys. Res. Commun. 209: 907-915

41. Naito M, Nagashima K, Mashima T and Tsuruo T (1997) Phosphatidylserine externalization is a downstream event of interleukin-1 beta-converting enzyme family protease activation during apoptosis. Blood 89: 2060-2066

42. Zamzami N, Marchetti P, Castedo M, Zanin C, Vayssiere JL, Petit PX and Kroemer G (1995) Reduction in mitochondrial potential constitutes an early irreversible step of programmed lymphocyte death in vivo. J. Exp. Med. 181: $1661-1672$

43. Bortner CD and Cidlowski JA (1999) Caspase independent/dependent regulation of $\mathrm{K}(+)$, cell shrinkage, and mitochondrial membrane potential during lymphocyte apoptosis. J. Biol. Chem. 274: 21953-21962

44. Hildeman DA, Mitchell T, Teague TK, Henson P, Day BJ, Kappler J and Marrack PC (1999) Reactive oxygen species regulate activation -induced $\mathrm{T}$ cell apoptosis. Immunity 10: 735-744

45. Bamji SX, Majdan M, Pozniak CD, Belliveau DJ, Aloyz R, Kohn J, Causing CG and Miller FD (1998) The p75 neurotrophin receptor mediates neuronal apoptosis and is essential for naturally occurring sympathetic neuron death. J. Cell. Biol. 140: $911-923$

46. Hirano A, Longo DL, Taub DD, Ferris DK, Young LS, Eliopoulos AG, Agathanggelou A, Cullen N, Macartney J, Fanslow WC and Murphy WJ (1999) Inhibition of human breast carcinoma growth by a soluble recombinant human CD40 ligand. Blood 93: 2999-3007

47. Hess S and Engelmann $\mathrm{H}(1996)$ A novel function of CD40: induction of cell death in transformed cells. J. Exp. Med. 183: 159-167

48. Lee SY, Park CG and Choi Y (1996) T cell receptor-dependent cell death of T cell hybridomas mediated by the CD30 cytoplasmic domain in association with tumor necrosis factor receptor-associated factors. J. Exp. Med. 183: 669-674

49. Prasad KVS, Ao Z, Yoon Y, Wu MX, Rizk M, Jacquot S and Schlossman SF (1997) CD27, a member of the tumornecrosis receptor family, induces apoptosis and binds to siva, a proapoptotic protein. Proc. Natl. Acad. Sci. USA 94: 63466351

50. Gruss HJ, Boiani N, Williams DE, Armitage RJ, Smith CA and Goodwin RG (1994) Pleiotropic effects of the CD30 ligand on CD30-expressing cells and lymphoma cell lines. Blood 83: 2045-2056

51. Wu MY, Wang PY, Han SH and Hsieh SL (1999) The cytoplasmic domain of the lymphotoxin-beta receptor mediates cell death in HeLa cells. J. Biol. Chem. 274: $11868-11873$

52. Wiley SR, Cassiano L, Lofton T, Davis-Smith T, Winkles JA, Lindner V, Liu H, Daniel TO, Smith CA and Fanslow WC (2001) A novel TNF recpetor family memberbinds TWEAK and is implicated in angiogenesis. Immunity 15: 837-846 
53. Alexander-Miller MA, Derby MA, Sarin A, Henkart PA and Berzofsky JA (1998) Supraoptimal peptide-major histocompatibility complex causes a decrease in bc1-2 levels and allows tumor necrosis factor alpha receptor II- mediated apoptosis of cytotoxic T lymphocytes. J. Exp. Med. 188: 1391-1399

54. Chiarle R, Podda A, Prolla G, Podack ER, Thorbecke GJ and Inghirami G (1999) CD30 overexpression enhances negative selection in the thymus and mediates programmed cell death via a Bcl-2-sensitive pathway. J. Immunol. 163: 194-205

55. Kawahara A, Ohsawa Y, Matsumura H, Uchiyama Y and Nagata S (1998) Caspase-independent cell killing by Fas-associated protein with death domain. J. Cell. Biol. 143: 1353-1360

56. Lemaire C, Andreau K, Souvannavong V and Adam A (1998) Inhibition of caspase activity induces a switch from apoptosis to necrosis. FEBS Lett. 425: $266-270$

57. Kataoka T, Budd RC, HollerN, Thome M, Martinon F, Irmler M, Burns K, Hahne M, Kennedy N, Kovacsovics M and Tschopp J (2000) The caspase-8 inhibitor FLIP promotes activation of NF-kappaB and Erk signaling pathways. Curr. Biol. 10: 640-648

58. Lorenzo HK, Susin SA, Penninger J and Kroemer G (1999) Apoptosis inducing factor (AIF): a phylogenetically old, caspase- independent effector of cell death. Cell Death Differ. 6: 516-524

59. Zamzami N and Kroemer G (1999) Condensed matter in cell death [news; comment]. Nature 401: 127-128

60. Sidoti-de Fraisse C, Rincheval V, Risler Y, Mignotte B and Vayssiere JL (1998) TNF-alpha activates at least two apoptotic signaling cascades. Oncogene 17: $1639-1651$

61. Chen MC, Hsu TL, Luh TY and Hsieh SL (2000) Overexpression of bcl-2 enhances LIGHT-and interferon-gamma-mediated. J. Biol. Chem. 275:38794 38801

62. Veldman RJ, Klappe K, Hoekstra D and Kok JW (1998) Interferon-gammainduced differentiation and apoptosis of HT29 cells: dissociation of (glucosyl)ceramide signaling. Biochem. Biophys. Res. Commun. 247: 802-808

63. Davis RJ (2000) Signal transduction by the JNK group of MAP kinases. Cell 103: $239-252$

64. Wu YL, Jiang XR, Newland AC and Kelsey SM (1998) Failure to activate cytosolic phospholipase A2 causes TNF resistance in human leukemic cells. J. Immunol. 160: $5929-5935$
65. Baker SJ and Reddy EP (1998) Modulation of life and death by the TNF receptor superfamily. Oncogene 17: 3261-3270

66. VanArsdale TL, VanArsdale SL, Force WR, WalterBN, Mosialos G, KieffE, Reed JC and Ware CF (1997) Lymphotoxin-beta receptor signaling complex: role of tumor necrosis factor receptor-associated factor 3 recruitment in cell death and activation of nuclear factor kappaB. Proc. Natl. Acad. Sci. USA 94: 2460-2465

67. Baud V and Karin M (2001) Signal transduction by tumor necrosis and its relatives. Trands Cell Biol. 11: 372-377

68. Nylandsted J, Rohde M, Brand K, Bastholm L, Elling F and Jaattela M (2000) Selective depletion of heat shock protein 70 (Hsp70) activates a tumor-specific death program that is independent of caspases and bypasses Bcl-2. Proc. Natl. Acad. Sci. USA 97: 7871-7876

69. Ravagnan L, Gurbuxani S, Susin SA, Maisse C, Daugas E, Zamzami N, Mak T, Jaattela M, Penninger JM, Garrido C and Kroemer G (2001) Heat-shock protein 70 antagonizes apoptosis-inducing factor. Nat. Cell. Biol. 3: 839-843

70. Browning JL, Miatkowski K, Griffiths DA, Bourdon PR, Hession C, Ambrose CM and Meier W (1996) Preparation and characterization of soluble recombinant heterotrimeric complexes of human lymphotoxins alpha and beta. J. Biol. Chem. 271: $8618-8626$

71. Jakubowski A, Browning B, Lukashev M, Sizing I, Thompson JS, Benjamin CD Hsu YM, Ambrose C, Zheng TS and Burkly LC (2002) Dual role for TWEAK in angiogenic regulation. J. Cell. Sci. 115: 267-274

72. Browning JL, Sizing ID, Lawton P, Bourdon PR, Rennert PD, Majeau GR, Ambrose CM, Hession C, Miatkowski K, Griffiths DA, Ngam-ek A, Meier W, Benjamin CD and Hochman PS (1997) Characterization of lymphotoxin-alpha beta complexes on the surface of mouse lymphocytes. J. Immunol. 159: 3288 3298

73. Martin SJ, Reutelingsperger CP, McGahon AJ, Rader JA, van Schie RC, LaFace DM and Green DR (1995) Early redistribution of plasma membrane phosphatidylserine is a general feature of apoptosis regardless of the initiating stimulus: inhibition by overexpression of Bcl-2 and Abl. J. Exp. Med. 182: 15451556 